\title{
THE MODEL DESIGN MODIFICATION OF SUNLIGHT DETECTION SYSTEM ON SOLAR CELL
}

\author{
Sutrisno, As'ad Aris Mustofa, Wawan Kusdiana Okol Sri Suharyo \\ Indonesian Naval Technology College, STTAL \\ Bumimoro-Morokrembangan, Surabaya 60187, Indonesia
}

\begin{abstract}
Indonesia is a country traversed by the equator therefore get a high intensity of sunlight from morning to afternoon, it can be utilized by utilizing solar power to be converted into electrical energy, that is using solar panels. The performance of solar panels is strongly influenced by the intensity of sunlight. Therefore it is Necessary to design a tool in the form of solar tracker that can move the solar panels to the position of the solar panels can always follow the direction of the coming sun. Currently there is already doing research with solar tracker but limited to move only east and west course, this will be more optimal if solar tracker can follow sunshine from all direction. In this research we managed to modify the models of a solar tracker that can move in direction east, west, north and south following the sun. The conclusion of this research is Obtained with the use of solar tracking system 2 degrees of freedom can reach a power increase of 11\% Compared to the solar tracking system 1 degree of freedom.
\end{abstract}

Keywords: Solar tracker 2 degrees of freedom, Solar cell.

\section{INTRODUCTION.}

\subsection{Background}

When electrical energy is the energy that is essential for human life. But today, the availability of electric energy sources are not able to meet the increasing demand for electricity in Indonesia, the energy requirement in general is increasing from year to year in line with population growth, economic growth and energy consumption patterns itself.

One effort to overcome the electricity crisis is utilizing solar energy sources. Potential of solar resources can be used optimally by designing an energy conversion system that can supply energy needs. The use of solar energy source has several advantages such as the availability of energy sources free of charge, so that environmentally friendly pollution-free, and unlimited.

Solar cell can deliver maximum power if the position Solar cell perpendicular to the direction of the sun. Most current solar cell mounted fix, so less than the maximum power generated. To solve it is necessary to design a tool that is a detection system for the position of the sun Solar cells are perpendicular to the direction of the sun.

\subsection{Formulation of the problem}

Based on the background described above, the formulation of the issues discussed are as follows

a. How do I create a detection system to maximize sunlight from solar panels based Microcontroller Arduino Uno with 2 degrees of freedom? b. What is the ratio of power generated by the solar panel solar tracker system 2 degrees of freedom and solar tracker 1 degree of freedom?

\subsection{Research purposes}

To answer all the questions in the formulation of the above problems, this study has the following objectives:

a. Designing a solar tracker system with two degrees of freedom in order to maximize the working of solar panels based Microcontroller Arduino Uno to follow the direction of sunlight from all directions.

b. Knowing the ratio of power produced by the solar panels are sunlight detection system with two degrees of freedom with detection of sunlight 1 degree of freedom.

\subsection{Benefits of Research}

The benefits of this final project is as follows:

a. To provide information to the public in general and the Navy in particular about the advantage's diesel fuel tracker-based microcontroller as an alternative energy power plant in Indonesia.

b. Providing solutions energy shortages that exist at the moment.

C. Solar cells provide a solution that is used to produce maximum power.

\subsection{Scope of problem} problem:

In This writing has restricted the scope of the

a. Microcontroller used is the Arduino Uno. 
b. The direction of motion and a motion in accordance with a light sensor that is attached using the LDR (Light Depending Resistor).

\section{THEORETICAL BASIS}

\subsection{Work principle Solar Cell}

Solar cells or solar cell is a device or component that can convert sunlight energy into electrical energy using photovoltaic effect principle. The meaning of Photovoltaic Effect is a phenomenon in which the rise of the power supply voltage for their relationship or contact of two electrodes connected to the system while getting a solid or liquid light energy. Therefore, solar cells or solar cell often called Photovoltaic cells (PV). Electric current arising due to the photon energy of sunlight it receives succeeded in liberating electrons in the semiconductor connection type $\mathrm{N}$ and $\mathrm{P}$ type to flow Sunlight is composed of extremely small particles called photons. When exposed to sunlight, photons are particles of the sun rays hit atom silicon semiconductor solar cells, giving rise to considerable energy to separate electrons from their atomic structure. Separate electrons and charged negative $(-)$ will be free to move in the area of the conduction band of the semiconductor material. Atoms that lose electrons will be a vacuum in the structure, the gap called the "hole" with a positive charge (+).

Semiconductor region with these free electrons are negative and acts as an electron donor, semiconductor region is called the $\mathrm{N}$-type semiconductor (n-type). While the semiconductor region with Hole are positives and act as Receiver (Acceptor) electrons, called the P-type semiconductor (P-type).

At the crossroads of the Positive and Negative (PN Junction), will generate energy to drive electrons and holes to move in the opposite direction. Electrons will move away from the negative area, while Hole will move away from the area positives. When given a load in the form of lights or other electrical devices at the Crossroads of the Positive and Negative (PN Junction), it will generate electricity flows.

\subsection{Solar Tracker Systems}

Sun tracker is the perfect solution for users of solar power plants especially in the utilization of solar energy that solar panels can produce maximum energy. This tool serves as a controller position solar panels to always be perpendicular to the direction of sunlight start the morning until late afternoon

This automatic sun tracker using the sensor as a receiver sunlight. The components used are photodiode, RPS, microcontrollers, motor drivers, DC motors gearbox. The working principle of this device is a sensor of a photodiode receives sunlight, passed to the signal conditioning circuit for changing the voltage level that we want, forwarded to the microcontroller to continue the program, and then send a signal to a motor driver to drive a DC motor gearbox, so that the tool will follow the direction of of the sun. This automatic sun tracker has reset automation system. When the position of the sun is on the west and position tracking are also heading west then the tracker will be reset in accordance with a predetermined angle limit through the program

\section{RESEARCH METHODOLOGY}

The basic concept of this research can be described through a flowchart as Figure 3.1 below, which describes the basic flow of research from the first step taken for research to preparing reports:

\subsection{Flowchart Diagram.}

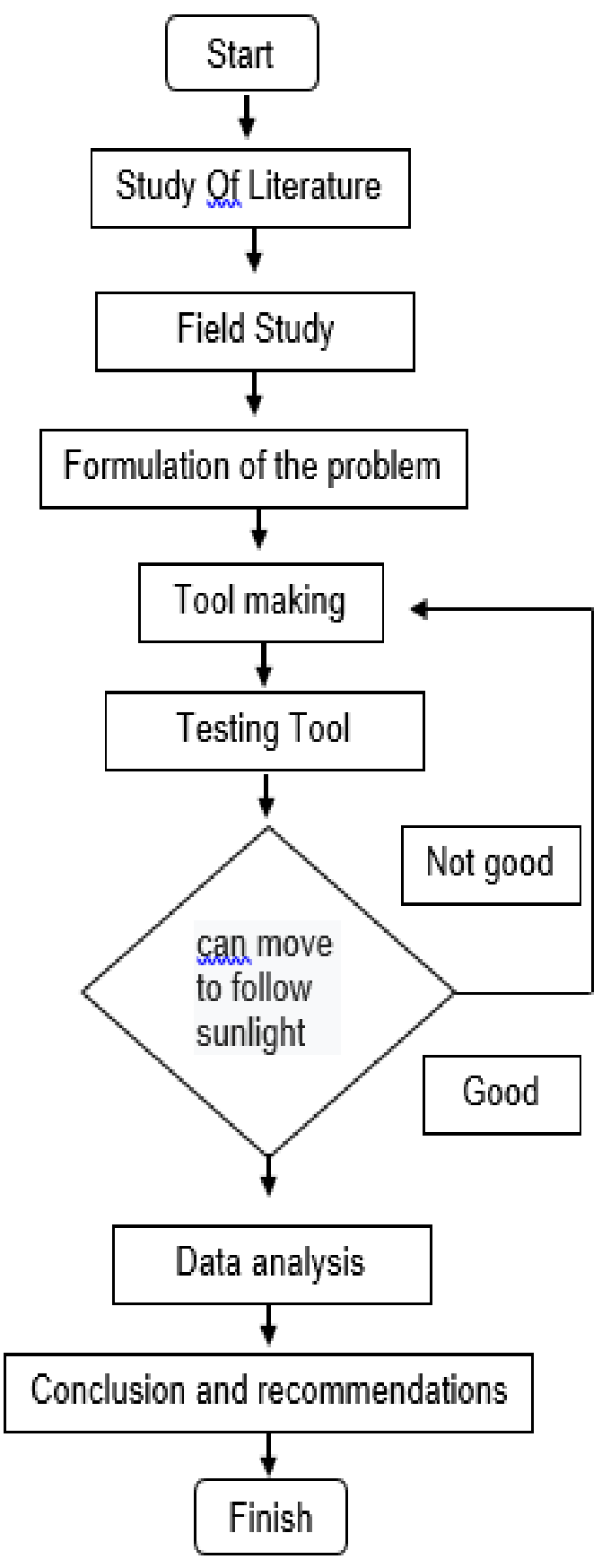

Figure 1. Flow Flow Basic Research 


\subsection{Hardware Design}

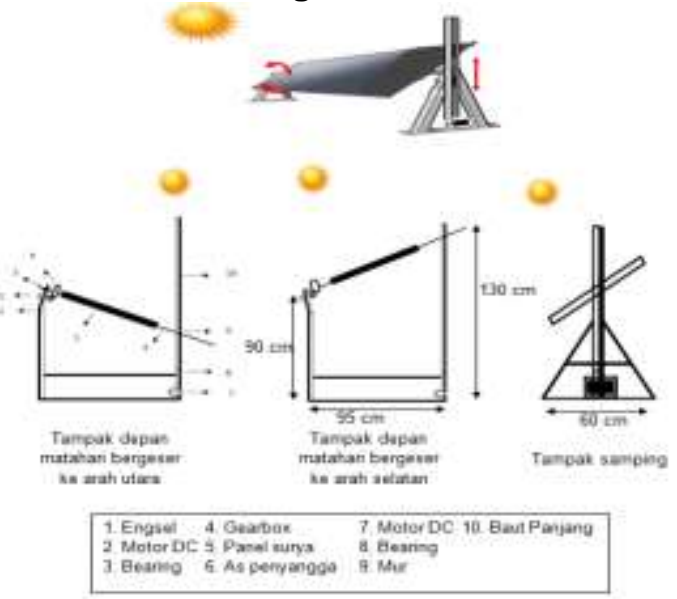

Figure 2. Solar Tracker 2 Degrees of Freedom

Model Solar tracker has two motors that can move the solar panels to the east, west, located on the left side and move up and down so as to direct the solar panels to the north, the south is located at the bottom right. Motor used is a DC motor that has a low RPM, because to move the solar panels to follow the direction of sunlight does not require quick movement. Solar panels used $50 \mathrm{wp}$ have a dimension of $700 \times 510 \times 30 \mathrm{~mm}$ with a weight of 4.5 $\mathrm{kg}$. Manufacture solar tracker system is designed to be able to work and have a static characteristics based electronic systems and mechanical systems are used. The electronic system uses light sensor LDR (Light Depending Resistor), which is placed in the middle of each side of the solar panel,

\subsection{Design of Electronic Devices}

In the electronic hardware there are some design, working on a system to maximize sunlight detection system then needs to be described the block diagram as shown below:

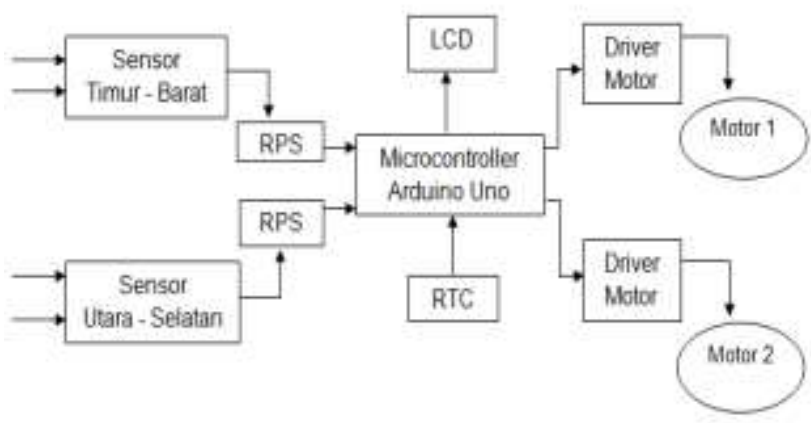

Figure 3. Block Diagram

The function of each component of the block diagram are:

a. photodioda which is used as the sensor is a type of diode that resistance changing if the light falling on the diode fluctuations in intensity.

b. RPS (Signal Conditioning circuit) is a circuit to convert the voltage level in accordance with what we want. c. Microcontroller is a controller chip that serves as an electronic circuit and generally can store programs therein.

d. RTC module Namely in the form of IC which has its own clock source and internal battery that stores data of time and date.

e. driver Motor is a circuit made up of transistors that are used to drive a DC motor.

f. Gearbox DC motor is a DC motor that has been equipped with a number of gear, resulting in a steady rotation and has great torque. The gear motors have an input voltage of $12 \mathrm{~V}$ DC

\subsection{Design Software}

To run a hardware system that has been designed and realized the circuit, it is necessary software for collect this microcontroller-based system. Software designed must meet the criteria and program memory capacity owned by the microcontroller used. In designing this software consists of several sub-systems required by the microcontroller used, namely, early after on power microcontrollers have to initialize the port associated with the use of the port of the microcontroller in order to work and the speed at which the data should be adjusted to the speed of data reading RTC and acces DC motor and sensor readings.

\section{TESTING AND DISCUSSION}

Once the design and manufacture of circuits implemented then the next step is to test the circuit one by one and then testing the circuit as a whole and the discussion of the system already built.

\subsection{LDR Sensor Networks Testing and Signal Conditioning}

In a series of LDR sensors with signal conditioning circuit, there are 3 points of measurement / test point. Measurement points include test point voltage at the LDR (Light Depending Resistor) which is the input (-) of the signal conditioning circuit as TP1 and the input side $(+)$ on the signal conditioning circuit is used as the reference voltage and the output voltage comparator circuit / comparator as TP3. The measurement points can clearly be seen in Figure 4.1 below.

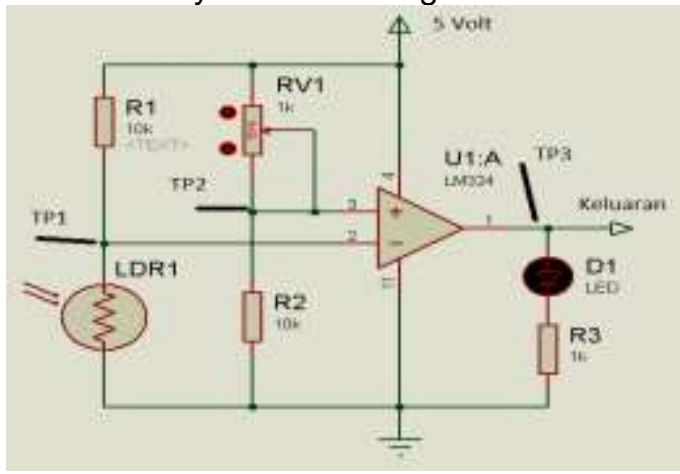

Figure 4. Test Point Sensor Networks 
Of the three point test data obtained as shown in Table 1 At measurement points 2 and 3 , the measurement is made at the time of LDR (Light Depending Resistor) gets a light from a light source or when LDR (Light Depending Resistor) do not receive light.

Table 1. Sensor Networks Testing Results

\begin{tabular}{|c|c|c|c|c|c|}
\hline No. & $\begin{array}{c}\text { TP-1 } \\
\text { Ada cahaya } \\
\text { (Volt) }\end{array}$ & $\begin{array}{c}\text { TP-1 } \\
\text { Tdk ada cahaya } \\
\text { (Volt) }\end{array}$ & $\begin{array}{c}\text { TP-2 } \\
\text { Refensi } \\
\text { (Volt) }\end{array}$ & $\begin{array}{c}\text { TP-3 } \\
\text { Ada cahaya } \\
\text { (Volt) }\end{array}$ & $\begin{array}{c}\text { TP-3 } \\
\text { Tdk Ada cahaya } \\
\text { (Volt) }\end{array}$ \\
\hline 1 & $1,3 \mathrm{~V}$ & $3,6 \mathrm{~V}$ & $4,5 \mathrm{~V}$ & $4,8 \mathrm{~V}$ & $0,3 \mathrm{~V}$ \\
\hline 2 & $1,4 \mathrm{~V}$ & $3,7 \mathrm{~V}$ & $4,5 \mathrm{~V}$ & $4,9 \mathrm{~V}$ & $0,4 \mathrm{~V}$ \\
\hline 3 & $1,3 \mathrm{~V}$ & $3,5 \mathrm{~V}$ & $4,5 \mathrm{~V}$ & $4,7 \mathrm{~V}$ & $0,3 \mathrm{~V}$ \\
\hline 4 & $1,2 \mathrm{~V}$ & $3,7 \mathrm{~V}$ & $4,5 \mathrm{~V}$ & $4,8 \mathrm{~V}$ & $0,2 \mathrm{~V}$ \\
\hline 5 & $1,3 \mathrm{~V}$ & $3,6 \mathrm{~V}$ & $4,5 \mathrm{~V}$ & $4,8 \mathrm{~V}$ & $0,3 \mathrm{~V}$ \\
\hline 6 & $1,4 \mathrm{~V}$ & $3,7 \mathrm{~V}$ & $4,5 \mathrm{~V}$ & $4,9 \mathrm{~V}$ & $0,4 \mathrm{~V}$ \\
\hline
\end{tabular}

\subsection{Minimum System Testing Arduino and DS1307 RTC}

The minimum system module testing Arduino UNO is performed to determine whether the circuit can work or not. This is done because even though the circuit is modular but sometimes there is damage to mikrokontroller. Testing includes pathways function port digital, analog and serial communication Arduino UNO-owned circuit.

Arduino UNO for module testing is done by connecting the circuit module RTC DS 1307, it also simultaneously test the RTC circuit. The next step charging module Arduino UNO program in advance using the Arduino IDE (Integrated Development Environment). By compiling the program we can find no fault / error or not the program that we created $\mathrm{SDH}$. To run the program, it first has to connect directly between computers with the Arduino UNO microcontroller module and proceed with the download program on using Arduino UNO Arduino IDE (Integrated Development Environment).

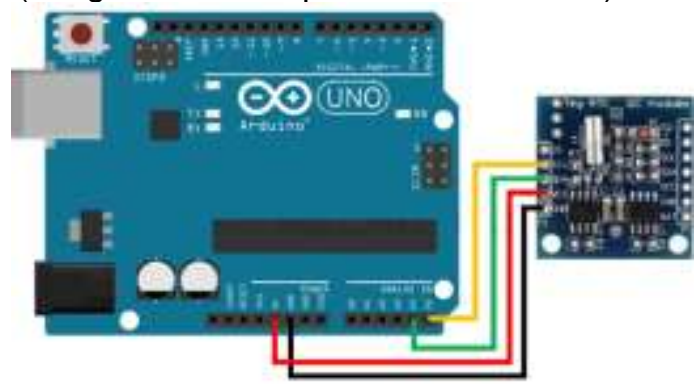

Figure 5. Relations Arduino UNO and DS1307 RTC

In this test the Arduino UNO microcontroller module will read the data hours, minutes, seconds, date, month and year of the next data will be sent to a PC via USB and serial communication showing on IDE serial monitor as shown in the picture below.

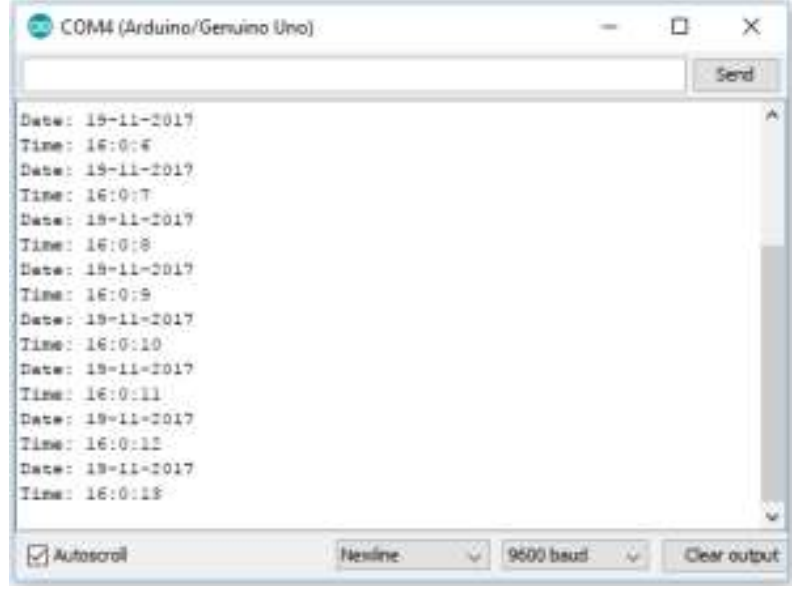

Figure 6. DS1307 RTC Data Display

Here is a sketch program to read the DS1307 RTC and transmit the data via serial port monitor on ARDUINO IDE.

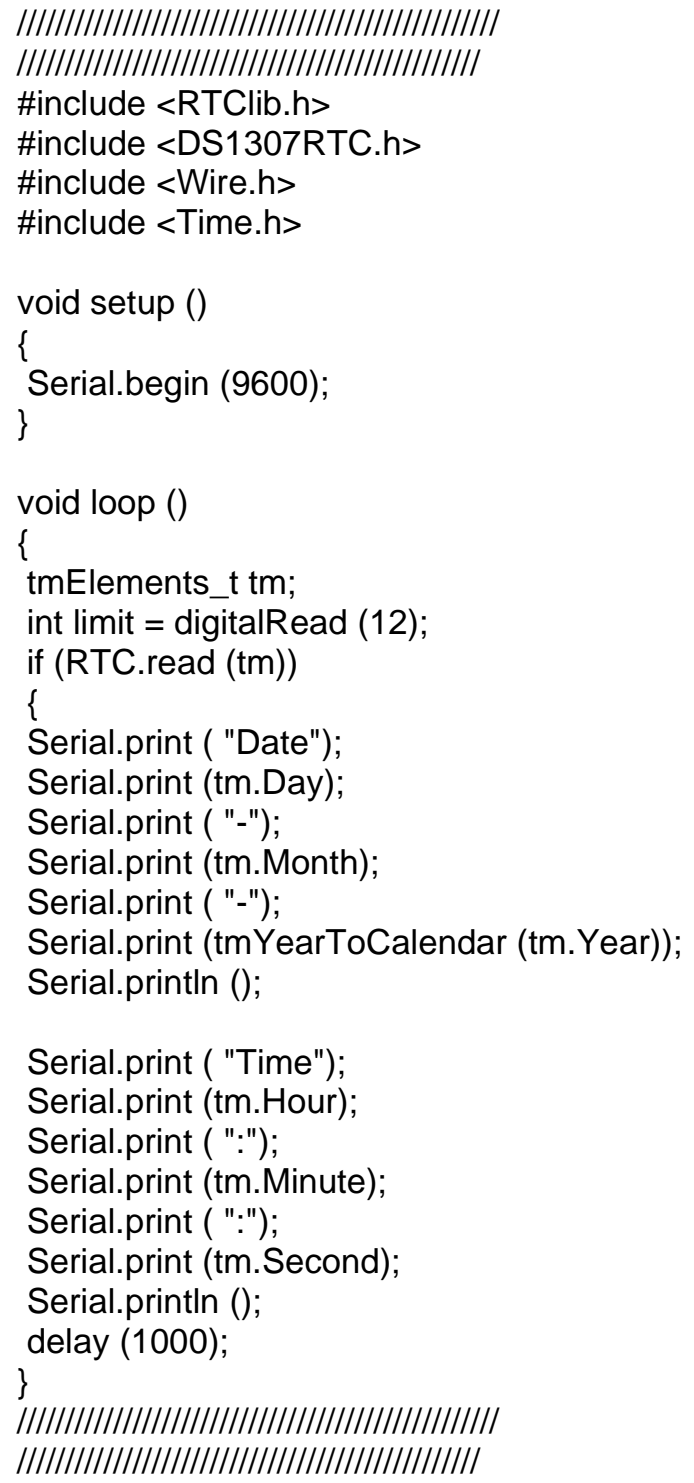




\subsection{Testing the LCD circuit I2C With Arduino UNO}

I2C $20 \times 4$ LCD module testing is done by connecting the 20X4 LCD module with Modules I2C and the Arduino UNO minimum system modules as in figure 4.4. by adding a program to display the text characters to be displayed on the LCD, it can be seen the response circuits or modules is mainly a response LCD to display the desired character. Program for text display 4 lines on the LCD I2C sketh form are as follows:

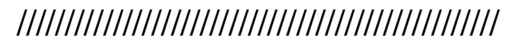

||||||||||||||||||||||||||||||||||||||||||||||||

\#include <Wire.h>

\#include <LiquidCrystal_I2C.h>

LiquidCrystal_I2C Icd (0x27,16,2);

void setup ()

\{

Icd.begin (20.4);

Serial.begin (9600);

\}

void loop ()

\{

Icd.setCursor (0.0);

Icd.print ( "Position Control Panel");

Icd.setCursor (0.1);

Icd.print ( "Based Solar Cells");

Icd.setCursor (0.2);

Icd.print ( "Arduino Uno R3");

Icd.setCursor (0.3);

Icd.print ( "By As'ad STTAL TM-36");

delay (2000);

\}

|||||||||||||||||||||||||||||||||||||||||||||||||||||

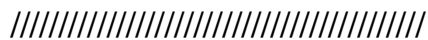

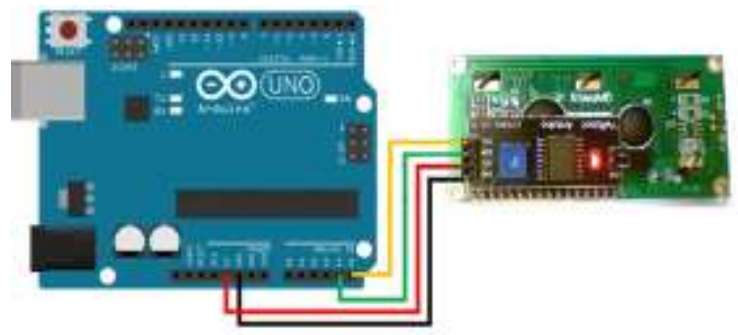

Figure 7. Arduino Uno LCD relationship with I2C $20 \times 4$

After the program was written in IDE ARDUINO later in the compilation to see if the program is right or wrong there. If there is no error in the program sketh can proceed to download a program file that is air-hex extension to the hardware ARDUINO.

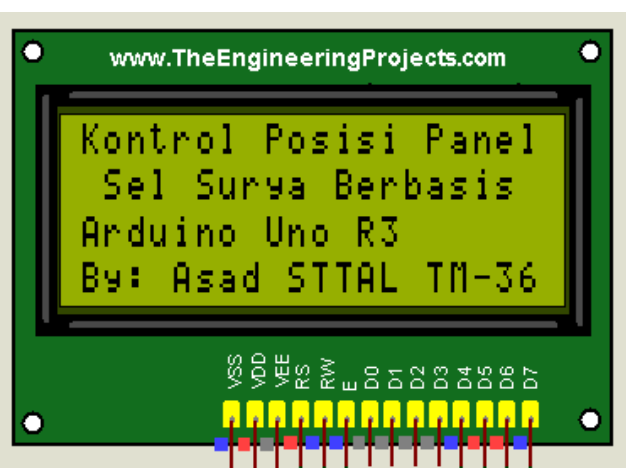

Figure 8. I2C 20X4 LCD Display

\subsection{Circuit Motor Driver}

The test is performed by signaling logic ' 0 ' and logika'1 'in the driver L293 which is used to drive a DC motor gearbox then the microcontroller should provide a logic' 0 'and' 1 'at the input of the motor driver according to the desired motion. Input motor driver 1 and 3 are combined into one as well as the input 2 and 4. to drive a DC motor gearbox (central lock) is connected to pin PB.0 and PB. 1 of the microcontroller. Data obtained from the test results as shown in Table 2.

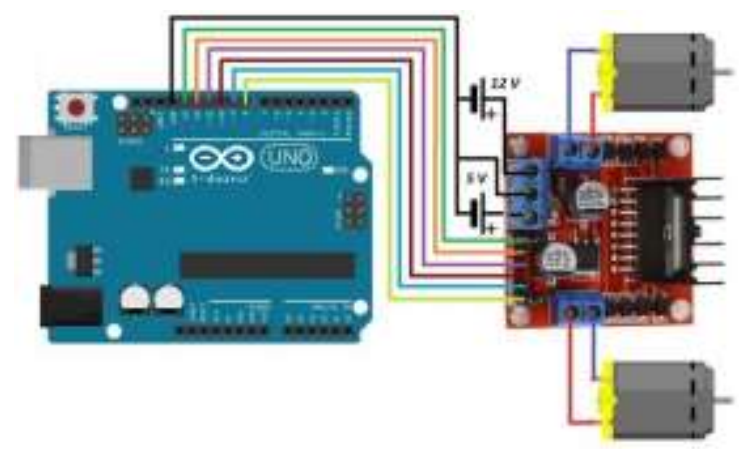

Figure 9. Arduino Uno relationship with DC Motor Driver L298

Table 2. Motor Driver Test Result Data

\begin{tabular}{|c|c|c|c|c|c|}
\hline $\begin{array}{l}\text { Kaki } \\
\text { En-A }\end{array}$ & $\begin{array}{c}\text { Kaki } \\
\text { Masukan }\end{array}$ & Motor-1 & $\begin{array}{l}\text { Kak } \\
\text { En-B }\end{array}$ & $\begin{array}{c}\text { Kako } \\
\text { Masukan }\end{array}$ & Motor-2 \\
\hline L & $\begin{array}{l}\text { Input } 1=0 \\
\text { nput } 3=0\end{array}$ & $\begin{array}{c}\text { Motor berputar } \\
\text { kekiri }\end{array}$ & L & $\begin{array}{l}\text { Input } 2=0 \\
\text { Input } 4=0\end{array}$ & $\begin{array}{c}\text { Motor berputar } \\
\text { kekin }\end{array}$ \\
\hline L & $\begin{array}{l}\text { Input } 1=0 \\
\text { nput } 3=0\end{array}$ & $\begin{array}{c}\text { Motor berputar } \\
\text { kekanan }\end{array}$ & L & $\begin{array}{l}\text { Input } 2=0 \\
\text { Input } 4=0\end{array}$ & $\begin{array}{c}\text { Motor berputar } \\
\text { kekanan }\end{array}$ \\
\hline H & $\begin{array}{l}\text { hout } 1=0 \\
\text { nout } 3=0\end{array}$ & $\begin{array}{c}\text { Motor tidak } \\
\text { bergerak }\end{array}$ & H & $\begin{array}{l}\text { Input } 2=0 \\
\text { Input } 4=0\end{array}$ & $\begin{array}{c}\text { Motor fidak } \\
\text { bergerak }\end{array}$ \\
\hline H & $\begin{array}{l}\text { nput } 1=0 \\
\text { nput } 3=0\end{array}$ & $\begin{array}{c}\text { Motor tidak } \\
\text { bergerak }\end{array}$ & H & $\begin{array}{l}\text { Input } 2=0 \\
\text { Input } 4=0\end{array}$ & $\begin{array}{c}\text { Motor Sdak } \\
\text { bergerak }\end{array}$ \\
\hline
\end{tabular}

From the above test results, it can be concluded that the DC motor driver to function properly, as it can control the direction of rotation of the motor by providing a different logic in PB. 0 and PB.1 so it can be used to drive a DC motor as the driving shaft gearbox Solar cell , 


\subsection{Testing Power DC Motor}

This test is used to determine how much power is required by a DC motor to drive the load of solar panels. In this case using two DC motors, namely:

a. $\mathrm{DC}$ motor drive the east-west direction

$\mathrm{P}=\mathrm{I} \times \mathrm{V}$

$=0.1 \times 12$ volt ampere

$=1.2 \mathrm{Watt}$

b. $\quad \mathrm{DC}$ motor drive the north-south direction

$\mathrm{P}=\mathrm{I} \times \mathrm{V}$

$=0.3 \times 12$ volt ampere

$=3.6 \mathrm{Watt}$

\subsection{Testing Systems Overall}

Overall model testing tool is to perform testing on the model tool that has been assembled as a whole are on the light source on the sensor. So it can be known whether the motor moves in accordance with the direction of the light or not,

Testing performance detector models the entire sunlight is divided into two tests. The first test is the test voltage, current and power output of solar cells solar detector with one degree of freedom and the second is the test voltage, current and power output of solar cells solar detector with two degrees of freedom. Both of these tests conducted in STTAL environment within two days, 28-29 November 2017 from 08.00 am until $15.00 \mathrm{pm}$ with data collection is done every hour.

Table 3. First Tests

\begin{tabular}{|c|c|c|c|c|c|c|c|}
\hline \multirow{2}{*}{$\begin{array}{c}\begin{array}{c}\text { Waktu } \\
\text { Pengujan }\end{array} \\
\text { (WiB) }\end{array}$} & \multicolumn{3}{|c|}{ I derapatkebebasan } & \multicolumn{3}{|c|}{2 derajatkebebasan } & \multirow{2}{*}{$\begin{array}{c}\text { Ket } \\
\text { Cuaca }\end{array}$} \\
\hline & $V(V)$ & $T(\mathrm{~A})$ & $P(W)$ & $V($ woll) & I(A) & $P(W)$ & \\
\hline 08.00 & 12,68 & 0.19 & 2,4 & 12,70 & 0.22 & 2,79 & Mendung \\
\hline 09.00 & 13,13 & 0,50 & 66 & 13,15 & 0,58 & 7,63 & Mendung \\
\hline 10.00 & 13,90 & 0,79 & 10,9 & 13,92 & 0.85 & 11,83 & Mendung \\
\hline 11.00 & 14,50 & 120 & 77.4 & 14,53 & 1,35 & 19.61 & Mendung \\
\hline 1200 & 14,40 & 1.27 & 18.29 & 14,42 & 1,31 & 18.89 & Mendung \\
\hline 13.00 & 14,97 & 1,15 & $\pi, 22$ & 15,00 & 1,25 & 18,75 & Mendung \\
\hline 14.00 & 15,26 & 0,45 & 6.87 & 15,26 & 0,58 & 8,86 & Mendung \\
\hline \multirow[t]{2}{*}{15.00} & 12,68 & 0,19 & 24 & 12,70 & 0,22 & 2,8 & Mendung \\
\hline & \multicolumn{2}{|c|}{ Daya rata-rata } & 10,21 & \multicolumn{2}{|c|}{ Daya rata-rata } & 11,4 & \\
\hline
\end{tabular}

\section{The resulting average comparison chart}

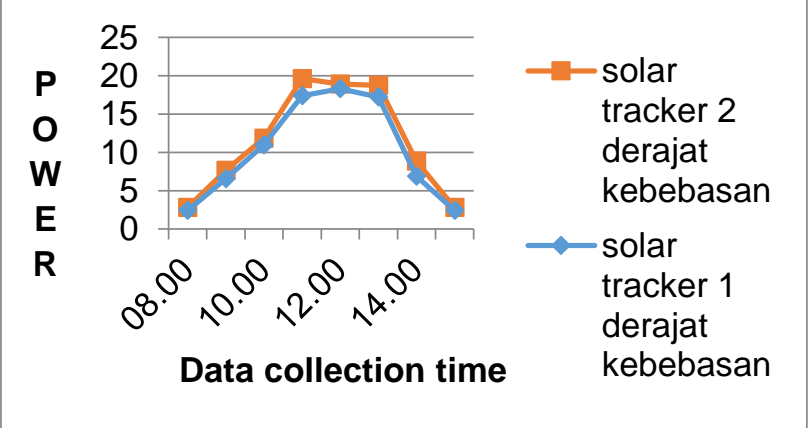

Figure 10. Graph First Test Results
Table 3 and 10 above picture shows data for the power generated from the solar panels using either a Solar Tracking System with 2 degrees of freedom and one degree of freedom, with the difference between the power generated by the solar panels that use solar tracking system 2 degrees of freedom of 1.13 watts in a day

Improvement

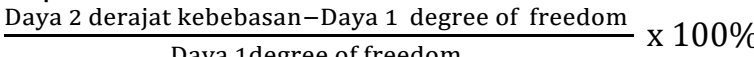

$$
\begin{aligned}
& \text { Daya 1degree of freedom } \\
& \qquad \begin{array}{l}
=\frac{11,4-10,27}{10,27} \times 100 \% \\
=11 \%
\end{array}
\end{aligned}
$$

\begin{tabular}{|c|c|c|c|c|c|c|c|}
\hline & \multicolumn{3}{|c|}{1 derajatkebebasan } & \multicolumn{3}{|c|}{2 derajatkebebasan } & \multirow{2}{*}{$\begin{array}{c}\text { Ket } \\
\text { Cuaca }\end{array}$} \\
\hline (WIB) & $V(V)$ & $T(A)$ & $P(W)$ & $V($ voll) & I(A) & $P(W)$ & \\
\hline 0800 & 13,9 & 1.8 & 25.02 & 13,92 & 1.91 & 26.59 & Cesah \\
\hline 0900 & 13,2 & 0,92 & 12.15 & 13.22 & 0,96 & 127 & Cerah \\
\hline 1000 & 17.5 & 2,15 & 37.63 & 17,50 & 2,34 & 40.85 & Cerah \\
\hline 1100 & 18.07 & 2,82 & 5096 & 18,10 & 2,94 & 5322 & Cerah \\
\hline 1200 & 15,1 & 0,98 & 148 & 15,10 & 1,00 & 151 & Mendung \\
\hline 1300 & 16.1 & 1,98 & 3189 & 16.10 & 2,15 & 3462 & Cerah \\
\hline 1400 & 16,9 & 1.6 & 27.04 & 17,05 & 1,83 & 31,2 & Cerah \\
\hline \multirow[t]{2}{*}{1500} & 14,13 & 0.49 & 6.92 & 14,15 & 0,62 & 8,78 & Mendung \\
\hline & \multicolumn{2}{|c|}{ Daya rata-rata } & 257 & \multicolumn{2}{|c|}{ Dava rata.rata } & 2789 & \\
\hline
\end{tabular}

Table 4. Testing Second

\section{The resulting average comparison chart}

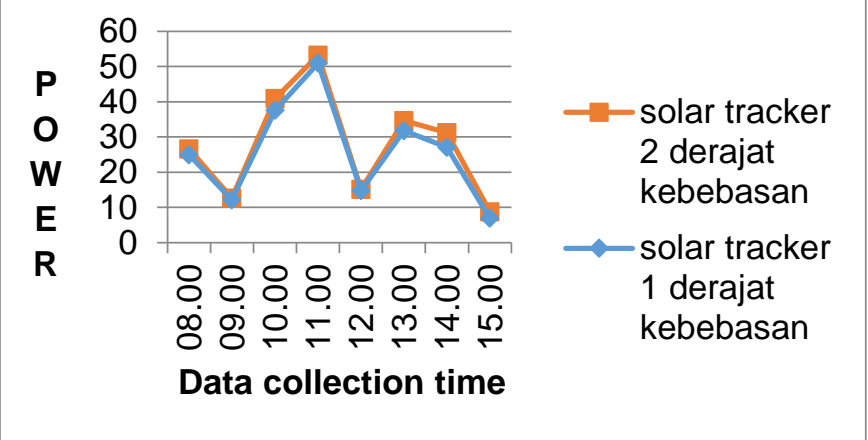

Figure 11. Graph First Test Results

Table 4 and Figure 11 above shows data for the power generated from the solar panels using either a solar tracking system with two degrees of freedom and one degree of freedom, with the difference between the power generated by the solar panels that use solar tracking system 2 degrees of freedom at 2.19 watts in a day

Improvement $=$

$$
\begin{aligned}
& \frac{\text { power } 2 \text { degree of freedom }- \text { power } 1 \text { dof }}{\text { power } 1 \text { degree of freedom }} \times 100 \% \\
& =\frac{27,59-25,7}{25,7} \times 100 \% \\
& =7.35 \%
\end{aligned}
$$

\subsection{Calculations Efficiency Solar Panel $50 \mathrm{Wp}$}

In the calculation of the efficiency of solar panels 50 wp needed some data, such as Pmax is 
the maximum output power generated by the solar panel voltage multiplied by the current formula. In this case we take the data solar tracker with two degrees of freedom as the highest power at \pm 11 o'clock on 29 november 2017 with sunny weather, with output power of 53.21 watts. Then A or dimension of $50 \mathrm{wp}$ solar panel itself is $70 \mathrm{~cm} \times 51$ $\mathrm{cm}=0.357 \mathrm{~m} 2$. Then the efficiency obtained by:

$$
\begin{aligned}
\eta \operatorname{Max}=\frac{\operatorname{Pmax}}{\mathrm{ExA}} \times & 100 \% \\
= & \frac{53,21 \text { watt }}{1000 \frac{\mathrm{W}}{\mathrm{m} 2} \times 0,357 \mathrm{~m} 2} \times 100 \% \\
& =14,9 \%
\end{aligned}
$$
efficiency.

So, the solar panel 50 existing wp has a $14.9 \%$

\section{CONCLUSION}

After going through the process of planning, design tools and testing phase partially resumed on the tool until the overall testing tools, it can be concluded as follows:

a. Has successfully designed a solar tracker system model 2 degrees of freedom by using an Arduino Uno with LDR sensor.

b. The average power generated by the solar panels of solar tracking system with two degrees of freedom in two times the test of 11.4 and 27.89 Watt Watt. While solar tracking system 1 degree of freedom of 10.27 Watts and 25.7 Watts.

c. Improvement of solar panels and solar tracking system 2 degrees of freedom at $11 \%$ and $7.35 \%$.

\section{ACKNOWLEDGEMENT}

The authors greatly acknowledge the support from Naval Technology College, STTAL Surabaya Indonesia for providing the necessary resources to carry out this research work. The authors are also grateful to the anonymous reviewers and journal editorial board for their many insightful comments, which have significantly improved this article.

\section{REFERENCES}

Atmel Corporation. (2011). Atmel LED Driver-MSL1060-Datasheets-complete. Retrieved from www.atmel.com

Dallas. (2006). Semiconductor DS1307.64x8, serial.i2c.Real-Time-Clock. Retrieved from www.maxim-IC.com

Hardianto, HE (2012). Prototype Design of a tracer of sunlight on solar power generation applications.

K, F. (2011). Efficiency Analysis Light Sensor (LDR, Photodioda and Phototransistor) On Fire Robot Design. Malang: UIN Maulana Malik Ibrahim.
Marsudi Sudarsono. (2011). Classes diktat 89C51 microcontroller. Poor.

Siew, H. (2008). Solar Tracker. ENG499 Capstone Project, 2008.

Sudarwanto, D. (2016). Design of Detection System For Optimizing Solar Absorption Solar In solar cell.

Umeno, PR (2011). new concept in solar cell. India. Saturn. (1992). basic electrical power engineering and power electronics. Jakarta: Pustaka Utama PT.Gramedia 